\title{
Depresi, ansietas, dan stres serta hubungannya dengan obesitas pada remaja
}

Relationship of depression, anxiety and stress with obesity in adolescent

Huriatul Masdar ${ }^{1}$, Pragita Ayu Saputri' ${ }^{1}$, Dani Rosdiana ${ }^{1}$, Fifia Chandra, Darmawi ${ }^{1}$

Fakultas Kedokteran Universitas Riau

\begin{abstract}
Background: Obesity can occur in all ages, including adolescents. Multiple factors were known related to obesity including psychological factor. Eating excessively could be response toward loneliness, grief or depression. Anxiety can contribute to determine the food intake and nutrient substance, and stress can cause behavioural disorders such as abnormal (excessive) eating behaviour that leads to obesity. Objective: The aimed of this research was to know depression, anxiety and stress and their relationship with obesity in adolescents in Pekanbaru. Method: A cross sectional research was performed, involving 132 subjects taken from 7 of 14 State Senior High Schools in Pekanbaru, 66 subjects were oerweight/obes and 66 subjects were normal. Body mass index per age was used to determine their nutritional status according to Indonesian Ministry of Health Standard 2010 for nutritional status of 5-18 years old children. Depression, anxiety and stress were measured by using DASS 42 scale, and categorized only into normal or having depression/anxiety/stress. Data were statistically analyzed by using Chi-Square test with significancy level $95 \%$. Results: The results showed $17.4 \%$ subjects were categorized depression, $65.2 \%$ were anxiety and $34.8 \%$ were stress. Statiscally analyzed using Fisher test showed that there were significantly association between depression with obesity ( $p=0.003 ;$ OR $=0.219)$ and stress with obesity $(p=0.044$, OR=0.028). Conclusion: Psychological aspects such as depression and stress were related to obesity in State Senior High Schools Students in Pekanbaru
\end{abstract}

KEY WORDS: adolescent; anxiety; depression; obesity; stress

\section{ABSTRAK}

Latar belakang: Obesitas dapat terjadi pada berbagai usia, termasuk pada remaja. Berbagai faktor berperan dalam terjadinya obesitas ini salah satunya faktor psikologi. Jumlah asupan makanan yang berlebihan bisa merupakan respon dari perasaan kesepian, dukacita atau depresi. Kecemasan juga berkontribusi besar dalam menentukan jumlah asupan makanan dan zat gizi, sedangkan stres dapat menyebabkan terjadinya perilaku makan yang tidak normal (berlebihan) yang bisa mengarah ke obesitas. Tujuan: Mengetahui depresi, ansietas dan stres pada remaja di Pekanbaru serta hubungannya dengan obesitas. Metode: Penelitian potong lintang dengan melibatkan 132 responden yg berasal dari 7 SMA Negeri dari 14 SMA Negeri yang ada di Pekanbaru. Sebanyak 66 responden memiliki status gizi gemuk/obes dan 66 responden memiliki status gizi kurus/normal. Status gizi ditentukan berdasarkan IMT/U pada anak usia 5-18 tahun yang ditetapkan Kementrian Kesehatan tahun 2010. Depresi, ansietas dan stres dinilai dengan menggunakan kuesioner kuesioner depression, anxietas, stress scale 42 (DASS 42) dan dikelompokkan menjadi tidak dan mengalami depresi/ ansietas/stres. Data dianalisis menggunakan uji Chi-Square dengan derajat kepercayaan 95\%. Hasil: Sebesar 17,4\% responden mengalami depresi; 65,2\% mengalami ansietas; dan 34,8\% mengalami stres. Terdapat hubungan bermakna antara depresi dengan obesitas $(p=0,005 ; O R=0,219)$ dan stres dengan obesitas $(p=0,044 ; O R=0,443)$. Simpulan: Faktor psikologi seperti depresi dan stres berhubungan dengan kejadian obesitas pada remaja di Pekanbaru

KATA KUNCI: remaja; ansietas; depresi; obesitas; stres

\section{PENDAHULUAN}

Masalah gizi lebih atau obesitas merupakan salah satu masalah kesehatan global, yang dikenal dengan new world syndrome yang dapat menimbulkan berbagai

Korespondensi: Huriatul Masdar, Fakultas Kedokteran Universitas Riau, Jl. Diponegoro 1 Pekanbaru, Telp. (0761) 839264 ext. 308, Fax. (0761) 839265 , e-mail: huriatul.masdar@lecturer.unri.ac.id 
masalah kesehatan, kecacatan maupun masalah finansial secara global $(1,2)$. Obesitas dapat terjadi baik di negara maju maupun negara berkembang, semua strata sosial dan ekonomi serta dapat mengenai berbagai usia. Dilaporkan sekitar 17\% anak dan remaja di Amerika Serikat mengalami obesitas (1). Di Indonesia, Riset kesehatan dasar (Riskesdas) tahun 2013 melaporkan bahwa terjadi peningkatan prevalensi obesitas pada anak di Indonesia. Pada kelompok anak usia 6-12 tahun terjadi peningkatan dari 9,2\% (tahun 2010) menjadi 18,8\% (tahun 2013), pada kelompok anak usia 13-15 tahun terjadi peningkatan dari 2,5\% (tahun 2010) menjadi 10,8\% (tahun 2013), dan pada kelompok anak usia 1618 tahun terjadi peningkatan dari 1,4\% pada tahun 2010 menjadi 7,3\% pada tahun $2013(3,4)$. Hal yang sama juga terlihat di Provinsi Riau, yaitu pada masing-masing kelompok usia anak terjadi peningkatan kejadian obesitas dari tahun 2010 ke tahun 2013 secara berturut-turut sebesar $10,9 \%$ menjadi $18 \%$ pada usia $6-12$ tahun; $2,2 \%$ menjadi $10 \%$ pada usia $13-15$ tahun; dan $1,0 \%$ menjadi $4,8 \%$ pada usia $16-18$ tahun $(3,4)$. Penelitian sebelumnya menunjukkan angka kejadian obesitas pada pelajar SMA Negri di Kota Pekanbaru sebesarnya 23,5\%, yaitu 56\% terjadi pada pelajar perempuan sedangkan $44 \%$ pelajar laki-laki (5).

Peningkatan yang cukup tinggi dari angka kejadian obesitas pada anak ini sangat mengkhawatirkan dan berisiko untuk munculnya penyakit-penyakit metabolik pada usia yang lebih dini. Penelitian di Iran (2013) menunjukkan sebesar 17,4\% anak usia sekolah di Timur Tengah dan Afrika Utara mengalami obesitas dan $15,4 \%$ dari siswa obes tersebut diidentifikasi mengalami sindroma metabolik (6). Penelitian lain di Amerika (2012) yang dilakukan pada anak usia 12-19 tahun menunjukkan 8,1\% anak mengalami sindroma metabolik (7).

Faktor-faktor yang dapat menyebabkan tingginya prevalensi obesitas pada anak ini dapat bersifat genetik maupun lingkungan. Keadaan psikologis anak juga disebutkan sebagai salah satu pemicu terjadinya obesitas. Pada orang-orang tertentu, makan berlebihan dapat terjadi sebagai respon dari suatu perasaan stres, depresi atau cemas. Hal ini apabila dibiarkan akan beresiko untuk menjadi obesitas. Hasil penelitian menunjukkan bahwa semakin tinggi stres yang dialami seseorang, semakin tinggi pula tingkatan indikator status gizinya. Di sisi lain, obesitas juga dapat mempengaruhi faktor kejiwaan seorang anak seperti merasa kurang percaya diri. Hal ini lebih terlihat pada anak usia remaja, biasanya akan menjadi pasif dan depresi dan cenderung tidak mampu bersosialisasi dengan teman sebayanya (8).

Penelitian ini bertujuan untuk melihat hubungan antara depresi, ansietas. dan stres terhadap kejadian obesitas pada remaja di Kota Pekanbaru. Penelitian ini diharapkan bisa mengidentifikasi salah satu faktor yang berkontribusi terhadap tingginya angka kejadian obesitas pada remaja di Kota Pekanbaru sehingga dapat direkomendasikan solusi untuk mengatasi masalah obesitas pada pelajar ini.

\section{BAHAN DAN METODE}

Penelitian ini adalah penelitian potong lintang dan telah mendapatkan persetujuan etik penelitian dari Unit Etika Penelitian Kedokteran dan Kesehatan Fakultas Kedokteran Universitas Riau dengan nomor 103/ UN.19.5.1.1.8/UNPKK/2015. Penelitian dilaksanakan pada bulan September sampai dengan November 2015. Sebanyak 132 orang responden (66 responden overweight/obes dan 66 responden normal) dipilih dengan menggunakan metode multistage purposive sampling. Responden diambil dari 7 SMA Negeri dari 14 SMA Negeri yang ada di Pekanbaru secara merata, rentang usia 15-18 tahun, dan memenuhi kriteria inklusi yaitu menyatakan kesediaan menjadi responden penelitian, tidak dalam keadaan sakit kronis yang dapat menyebabkan perubahan berat badan dan tidak sedang mengonsumsi obat-obatan, herbal, maupun suplemen yang dapat menaikan atau menurunkan berat badan.

Status gizi responden ditentukan dengan menggunakan standar antropometri penilaian status gizi anak yang tertuang dalam Keputusan Menteri Kesehatan Republik Indonesia nomor 1995 tahun 2010, yaitu dengan menggunakan indikator antropometri indeks masa tubuh dibandingkan usia (IMT/U) untuk anak usia 5-18 tahun. Pengukuran berat badan dilakukan dengan menggunakan timbangan injak. Pengukuran dilakukan dua kali per responden dan diukur hingga satu angka desimal. Pengukuran tinggi badan dilakukan dengan 
menggunakan microtoise. Pengukuran dilakukan dua kali pada masing-masing repsonden dan dinilai hingga satu angka desimal. Penetapan status gizi dilakukan dengan menggunakan WHO-anthroplus v1.0.4 software. Responden dengan status gizi gemuk dan obesitas ( $z$-score $>+1 \mathrm{SD})$ dikategorikan sebagai kelompok obes dan responden dengan status nutrisi sangat kurus, kurus, dan normal ( $z$-score $\leq+1 \mathrm{SD}$ ) dikategorikan sebagai kelompok non-obes.

Depresi, ansietas dan stres dinilai dengan menggunakan kuesioner Depression, Anxietas, Stress Scale 42 (DASS 42) yang dikeluarkan oleh Psychology Foundation Australia. Kuesioner yang digunakan adalah DASS 42 versi translasi ke bahasa Indonesia oleh Damanik E (9). Pada kuesioner ini terdapat masingmasing 14 pertanyaan untuk menilai adanya depresi, ansietas dan stres. Masing-masing pertanyaan memiliki skor 0 -3. Total skor $\leq 9, \leq 7$, dan $\leq 14$ secara berturut untuk masing-masing kategori depresi, ansietas maupun stres dinyatakan sebagai tidak depresi/ansietas/stres, dan sebaliknya skor diatas 9,7, dan 14 dinyatakan mengalami depresi, ansietas atau stres tanpa membedakan derajatnya. Hubungan depresi, stres, dan ansietas dengan status gizi diuji secara statistik dengan menggunakan uji ChiSquare.

Tabel 1. Gambaran depresi, ansietas, dan stres pada remaja di Pekanbaru $(n=132)$

\begin{tabular}{llcc}
\hline \multirow{2}{*}{ Variabel } & \multicolumn{2}{c}{ Kategori } & \multicolumn{2}{c}{ Jumlah } \\
\cline { 3 - 4 } & & $\mathbf{n}$ & $\mathbf{\%}$ \\
\hline Depresi & Tidak depresi (skor $\leq 9)$ & 109 & 82,6 \\
& Depresi (skor $>9$ ) & 23 & 17,4 \\
\multirow{4}{*}{ Ansietas } & Tidak ansietas (skor $\leq 7)$ & 46 & 34,8 \\
& Ansietas (skor $>7)$ & 86 & 65,2 \\
Stres & Tidak stres (skor $\leq 14)$ & 86 & 65,2 \\
& Stres $($ skor $>14)$ & 46 & 34,8 \\
\hline
\end{tabular}

\section{HASIL}

Penelitian ini melibatkan 132 responden yang diambil secara multistage purposive sampling, yang terdiri dari 66 orang responden memiliki status gizi dengan kategori gemuk/obes dan 66 orang memiliki status nutrisi kurus/normal sesuai kriteria yang ditetapkan oleh Kementrian Kesehatan pada tahun 2010. Responden berusia sekitar 15-18 tahun dengan rerata usia 16,28 tahun dan jenis kelamin laki-laki dan perempuan masingmasingnya sebanyak $50 \%$, baik pada kelompok obes maupun non-obes.

Hasil pemeriksaan psikologi responden dengan menggunakan DASS 42 menunjukkan bahwa sebanyak $17,4 \%$ responden mengalami depresi. Depresi ini lebih banyak ditemukan pada responden perempuan $(21,2 \%)$ dibandingkan lak-laki (13,4\%). Lebih lanjut, responden yang mengalami ansietas dan stres diperoleh masingmasing sebesar $65,2 \%$ dan $34,8 \%$ secara berturut-turut. Sama halnya dengan depresi, responden wanita terlihat lebih banyak mengalami ansietas dan stres dibandingkan laki-laki. Tidak terdapat hubungan yang bermakna antara jenis kelamin responden dengan depresi, ansietas maupun stres yang dialami (Tabel 1 dan 2).

Berdasarkan status gizinya, responden dengan status gizi tergolong obes sekitar 7,6\% mengalami depresi. Persentase ini lebih rendah dibandingkan responden yang terkategori non-obes yaitu 27,3\% dari responden yang tergolong non-obes mengalami depresi. Hasil analisis secara statistik dengan menggunakan uji Chi-Square menunjukkan adanya hubungan antara depresi dengan status gizi responden $(p=0,003)$ yaitu remaja yang mengalami depresi akan menjadi obes 0,219 kali dibandingkan remaja yang tidak obes. Ansietas ditemukan pada $60,6 \%$ responden yang terkategori obes dan $69,7 \%$ pada responden dengan kategori non-obes,

Tabel 2. Gambaran depresi, ansietas, dan stres berdasarkan jenis kelamin pada remaja di Pekanbaru (n=132)

\begin{tabular}{|c|c|c|c|c|c|c|c|}
\hline \multirow{2}{*}{ Variabel } & \multirow{2}{*}{ Kategori } & \multicolumn{2}{|c|}{ Laki-laki } & \multicolumn{2}{|c|}{ Perempuan } & \multirow{2}{*}{$\mathbf{p}$} & \multirow{2}{*}{ OR (IK 95\%) } \\
\hline & & $\mathbf{n}$ & $\%$ & $\mathbf{n}$ & $\%$ & & \\
\hline \multirow{2}{*}{ Depresi } & Tidak depresi (skor $\leq 9)$ & 57 & 86,7 & 52 & 78,8 & 0,251 & 1,705 \\
\hline & Depresi (skor >9) & 9 & 13,6 & 14 & 21,2 & & $(0,681-4,27)$ \\
\hline \multirow{2}{*}{ Ansietas } & Tidak ansietas (skor $\leq 7$ ) & 28 & 42,4 & 18 & 27,3 & 0,068 & 1,965 \\
\hline & Ansietas (skor >7) & 38 & 47,6 & 48 & 72,7 & & $(0,948-4,074)$ \\
\hline \multirow{2}{*}{ Stres } & Tidak stres (skor $\leq 14$ ) & 47 & 71,2 & 39 & 59,0 & 0,144 & 1,713 \\
\hline & Stres (skor >14) & 19 & 28,8 & 27 & 41,0 & & $(0,830-3,534)$ \\
\hline
\end{tabular}


Tabel 3. Gambaran depresi, ansietas, dan stres berdasarkan status nutrisi pada remaja di Pekanbaru (n=132)

\begin{tabular}{|c|c|c|c|c|c|c|c|}
\hline & \multirow{3}{*}{ Kategori } & \multicolumn{4}{|c|}{ Status gizi } & \multirow{3}{*}{$\mathbf{p}$} & \multirow{3}{*}{$\begin{array}{c}\text { OR } \\
(\text { IK 95\%) }\end{array}$} \\
\hline & & \multicolumn{2}{|c|}{ Non obes } & \multicolumn{2}{|c|}{ Obes } & & \\
\hline & & $\mathbf{n}$ & $\%$ & $\mathrm{n}$ & $\%$ & & \\
\hline \multirow{2}{*}{ Depresi } & Tidak depresi $($ skor $\leq 9)$ & 48 & 72,7 & 61 & 92,4 & \multirow{2}{*}{$0,003 *$} & 0,219 \\
\hline & Depresi (skor >9) & 18 & 27,3 & 5 & 7,6 & & $(0,076-0,631)$ \\
\hline \multirow{2}{*}{ Ansietas } & Tidak ansietas ( skor $\leq 7$ ) & 20 & 30,3 & 26 & 39,4 & \multirow{2}{*}{0,273} & 0,669 \\
\hline & Ansietas (skor >7) & 46 & 69,7 & 40 & 60,6 & & $(0,325-1,375)$ \\
\hline \multirow{2}{*}{ Stres } & Tidak stres $($ skor $\leq 14$ ) & 37 & 56 & 49 & 74,2 & \multirow{2}{*}{$0,028^{*}$} & 0,443 \\
\hline & Stres (skor >14) & 29 & 44 & 17 & 25,8 & & $(0,212-0,923)$ \\
\hline
\end{tabular}

* bermakna secara statistic $(\mathrm{p}<0,05)$

serta tidak terdapat hubungan antara ansietas dengan status gizi responden $(\mathrm{p}=0,273)$. Parameter psikologi lain yaitu stres ditemukan sebesar $25,8 \%$ pada responden terkategori obes dan $44,0 \%$ pada responden yang tidak terkategori obes dan terdapat hubungan yang bermakna secara statistik antara stres dan status gizi responden $(\mathrm{p}=0,028 ; \mathrm{OR}=0,443$ (Tabel 3).

\section{BAHASAN}

Gangguan psikologi baik itu depresi, ansietas maupun stres diduga menjadi salah satu faktor risiko terjadinya obesitas baik pada usia kanak-kanak maupun maupun muncul setelah usia dewasa (10). Berbagai bentuk stresor dapat memicu terjadinya depresi, ansietas, dan stres pada anak usia sekolah. Hal ini dapat berupa stresor yang berasal dari keluarga, lingkungan sekolah, baik itu stresor dari kegiatan akademik, guru maupun teman-teman sekolahnya (8).

Dalam penelitian ini ditemukan sebesar 17,4\% remaja di Pekanbaru mengalami depresi dan ditemukan bahwa perempuan lebih banyak mengalami depresi dibandingkan laki-laki. Depresi lebih cenderung banyak dialami oleh perempuan dibandingkan laki-laki dapat disebabkan oleh beberapa faktor diantaranya yaitu perempuan kurang asertif dan cenderung memiliki skor yang lebih rendah dalam hal kemampuan kepemimpinan daripada anak laki-laki, anak perempuan lebih sering menggunakan coping ruminatif dibanding anak laki-laki yaitu perempuan lebih memusatkan perhatiannya pada simptom-simptom depresi yang dialaminya. Sebaliknya, anak laki-laki cenderung mengalihkannya pada beberapa aktivitas fisik seperti menonton televisi, berperilaku agresif. Di samping itu, anak perempuan kurang dominan, kurang agresif baik secara fisik maupun verbal dalam berinteraksi dengan kelompoknya (11).

Kecemasan atau ansietas merupakan bentuk gangguan psikologi yang cukup banyak ditemukan pada remaja di Pekanbaru $(65,2 \%)$. Penelitian yang dilakukan pada pelajar salah satu SMA Negeri di Surakarta juga menunjukkan hasil yang sama yaitu sebanyak $60 \%$ responden mengalami gangguan kecemasan atau ansietas (12). Gangguan cemas merupakan gangguan yang banyak terjadi pada anak dan remaja. Gangguan kecemasan ini biasanya timbul karena perkembangan tidak tepat serta kekhawatiran yang berlebihan. Jenis kecemasan pada remaja dan anak usia sekolah secara signifikan dapat mengganggu kegiatan harian dan tugas-tugas perkembangan. Dalam penelitian ini, pelajar perempuan yang mengalami ansietas lebih banyak dibandingkan pelajar laki-laki. Hal ini juga sejalan dengan penelitian sebelumnya bahwa remaja dengan jenis kelamin perempuan lebih banyak yang mengalami kecemasan dibandingkan laki-laki (12). Jenis kelamin kadang berpengaruh dalam menentukan pertahanan diri seseorang terhadap kecemasan. Fobia sosial lebih banyak ditemukan pada laki-laki sedangkan pada fobia yang sederhana gangguan menghindar dan agoraphobia lebih banyak ditemukan pada remaja perempuan. Sementara cemas perpisahan, gangguan cemas menyeluruh, dan gangguan panik didapatkan pada kedua jenis kelamin (13).

Lebih lanjut, gangguan stres pada penelitian ini ditemukan juga lebih banyak pada pelajar perempuan $(41,0 \%)$ dibandingkan laki-laki $(28,8 \%)$. Penyebab stres pada remaja dapat dipicu dari kematian orang yang dicintai atau menyaksikan peristiwa yang traumatis, penyebab yang paling umum berhubungan dengan 
sekolah (seperti intimidasi dari teman-teman, masalah dengan guru, dan kesulitan akademis) dan hubungan interpersonal (seperti konflik dengan orang tua, saudara, dan teman sebaya) $(14,15)$. Sumber stres pada remaja laki-laki dan perempuan pada umumnya sama, hanya saja remaja perempuan sering merasa cemas ketika sedang menghadapi masalah sedangkan pada remaja laki-laki cenderung lebih berperilaku agresif. Remaja laki-laki yang mengalami stres akan melakukan perbuatan negatif seperti mengonsumsi rokok dan alkohol (13). Kemungkinan faktor tersebutlah yang menyebabkan stres pada perempuan lebih banyak jika dibandingkan dengan laki-laki.

Hasil analisis menunjukkan adanya hubungan yang bermakna secara statistik antara depresi dan stres dengan status gizi responden $(\mathrm{p}=0,003)$. Penelitian yang dilakukan di Minnesota terhadap 553 remaja dengan obesitas menunjukkan hal yang serupa, yaitu depresi yang dialami oleh responden dengan obesitas tersebut berhubungan dengan status gizinya. Adanya ketidakpercayaan diri yang dialami oleh remaja dengan obesitas akan pencitraan tubuhnya membuat mereka cenderung menarik diri dan menjadi depresi (15). Penelitian ini didukung hasil penelitian pada mahasiswa Fakultas Kedokteran Univeristas Lampung yang juga menemukan hal sama yaitu depresi memiliki hubungan yang bermakna dengan obesitas (16). Depresi merupakan salah satu faktor risiko terjadinya status gizi lebih dan status gizi kurang dan sebaliknya keadaan status gizi juga dapat menimbulkan depresi pada seseorang.

Hasil penelitian yang dilakukan di SMU Methodist-8 Medan juga menunjukkan adanya hubungan yang signifikan antara stres dengan status gizi, yaitu semakin tinggi skor stres seseorang semakin tinggi tingkatan status gizinya. Siswa yang memiliki status gizi gemuk dan obesitas mengalami stres sedang dan stres berat (17). Hal ini sejalan dengan hasil penelitian ini bahwa stres mempengaruhi kebiasaan makan seseorang, yaitu orang cenderung mencari makanan berkalori tinggi dan tinggi lemak selama periode stres. Berdasarkan survei yang dilakukan oleh American Psychology Association tahun 2013, sebesar 37\% dari remaja yang makan berlebihan atau makan makanan yang tidak sehat karena stres menyatakan bahwa hal tersebut adalah kebiasaan.
Sementara sebesar 33\% remaja menyatakan mereka melakukannya karena membantu mengalihkan perhatian mereka dari apa yang menyebabkan mereka stres dan hampir seperempat dari remaja melaporkan makan untuk mengelola stres (18).

Saat tubuh kita mengalami stres yang merupakan suatu ancaman dalam diri kita, seperti orang yang takut kegemukan, yang selalu mengkhawatirkan berat badannya, justru memicu kelenjar adrenal melepaskan kortisol lebih banyak sebagai respon alami tubuh terhadap stres. Tingginya kadar hormon kortisol akan merangsang tubuh untuk mengeluarkan hormon insulin, leptin, dan sistem neuropeptide Y (NPY) yang akan membuat otak membangkitkan rasa lapar sehingga timbul keinginan makan, pemilihan jenis makanan tinggi gula dan lemak, serta menimbulkan motivasi untuk mencari makanan berkalori tinggi yang menenangkan dan menyimpan kalori ekstra sebagai lemak di bagian perut (19).

Pada penelitian ini tidak menunjukkan adanya hubungan bermakna antara ansietas dengan kejadian obesitas ( $p=0,273)$. Hasil penelitian tidak sesuai dengan teori yang mengatakan bahwa kecemasan memiliki kontribusi yang besar dalam menentukan asupan makan dan zat gizi. Namun, perlu disadari bahwa penyebab terjadinya obesitas tidak hanya faktor psikologi. Jumlah asupan zat gizi dan aktivitas fisik juga merupakan faktor risiko yang berkontribusi besar terhadap kejadian obesitas.

\section{SIMPULAN DAN SARAN}

Faktor psikologi seperti depresi dan stres memiliki hubungan yang bermakna dengan status gizi pada remaja di Pekanbaru dan sebaliknya ansietas tidak memiliki hubungan yang bermakna dengan status gizi pada remaja di Pekanbaru. Faktor psikologi ini hanya merupakan salah satu faktor risiko pemicu terjadinya obesitas pada anak usia sekolah sehingga masih perlu diteliti lebih lanjut faktor-faktor risiko lain yang dapat menyebabkan tingginya angka kejadian obesitas pada remaja di Pekanbaru. Dengan demikian, diharapkan angka kejadian obesitas pada anak usia sekolah dapat ditekan dan risiko munculnya gangguan akibat obesitas pada usia dini itu dapat dicegah. 


\section{UCAPAN TERIMA KASIH}

Sumber dana penelitian ini berasal dari dana DIPA Fakultas Kedokteran Universitas Riau tahun 2015.

\section{Pernyataan konflik kepentingan}

Penulis menyatakan tidak ada konflik kepentingan dengan pihak-pihak yang terkait dalam penelitian ini.

\section{RUJUKAN}

1. Ogden CL, Carroll MD, Kit BK, Flegal KM. Prevalence of obesity and trends in body mass index among US children and adolescent, 1999-2010. JAMA 2012;307:483-90.

2. Hadi H. Gizi lebih sebagai tantangan baru dan implikasinya terhadap kebijakan pembangunan kesehatan nasional. Ju

3. rnal Gizi Klinik Indonesia 2004;1(2):51-8.

4. Badan Penelitian dan Pengembangan Kesehatan. Riset kesehatan dasar (Riskesdas) 2010. Jakarta: Departemen Kesehatan RI; 2011.

5. Badan Penelitian dan Pengembangan Kesehatan. Riset kesehatan dasar (Riskesdas) 2013. Jakarta: Departemen Kesehatan RI; 2014.

6. Masdar H, Chandra F, Rosdiana D, Rica A, Hijratinisa M. Undiagnosed diabetes mellitus identification on state Senior High School students in Pekanbaru with obesity. Proceeding of Update Infectious Disease Management in Daily Practice; 2014.

7. Lakshman, Elks CE, Ong KK. Chilhood obesity. Circulation 2012;126:1770-9.

8. Roberts CK, Shields M, De Groh M, Aziz A, Gilbert J. Overweight and obesity in children and adolescents. Statistics Canada, Catalogue 2012;23(3):1-7.

9. Nemiary D, Shim R, Mattox G, Holden K. The relationship between obesity and depression among adolescents. Psychiatr Ann 2012;42(8):305-8.
10. Psychology Foundation of Australia. Depression anxiety stress scales. [series online] 2014 [cited October 2015]. Available from: URL: http://www2. psy.unsw.edu.au/dass/Indonesian/Damanik.htm

11. Haslam DW, James WP. Obesity. Lancet 2005;356:213-5.

12. Kring AM, Jhonson SL, Davison GC, Neale JM. Abnormal psychology. 12th ed. New York: Wiley Publisher; 2012.

13. Kurniawati A. Perbedaan tingkat kecemasan pada remaja dengan ciri kepribadian introvert dan ekstrovert di kelas X SMA Negeri 4 Surakarta [Skripsi]. Surakarta: Universitas Muhammadiyah Surakarta; 2012.

14. Zimmer-Gembeck MJ, Skinner EA. Adolescents coping with stress: development and diversity. School Nurse News 2010;27(2):23-8.

15. Purwati S. Tingkat stres akademik pada mahasiswa reguler angkatan 2010 Fakultas Ilmu Keperawatan Universitas Indonesia [Skipsi]. Jakarta: Universitas Indonesia; 2012.

16. Goldschmidt AB, Wall MW, Loth, KA, NeumarkSztainer D. Risk factors for disordered eating in overweight adolescents and young adults. J Ped Psy 2015;1-6.

17. Angraini DI. Hubungan depresi dengan status gizi. Medula Unila 2014;2(2):39-46.

18. Nadeak TAU, Siagian A, Sudaryati E. Hubungan status stres psikososial dengan konsumsi makanan dan status gizi siswa SMA Methodist-8 Medan. Jurnal Penelitian FKM USU 2013;2(6).

19. American Psychological Association. Stress in America survey infographics. [series online] 2013 [cited April 2015]. Available from: URL: www.apa. org/news/press/releases/stress/2013/eating.aspx.

20. Yau YHC, Potenza MN. Stress and eating behaviours. Minerva endocrinol 2013;38(3):255-67. 